\title{
Notary Responsibility to the Delay in Registration of Limited Liability Companies in Legal Entity Administration System (SABH) Ministry of Law and Human Rights In Accordance with Law Number $\mathbf{4 0}$ year 2007 concerning Limited Liability Companies
}

\author{
Meta Budiani ${ }^{1}$ and Amin Purnawan ${ }^{2}$
}

\begin{abstract}
Limited Liability Company is an alliance of several people to conduct a business whose capital comes from shares owned by the members. Limited Liability Company in the current era is very much needed as the economic development. The method used was an empirical juridical method with descriptive analytical research specifications, while the data analysis method used was qualitative analysis. Based on the results of the research and discussion, it can be concluded that the delay in the registration of the establishment of a Limited Liability Company in the Legal Entity Administration System (SABH) of the Ministry of Law and Human Rights can be overcome by using the Confirmation deed on the previous deed of establishment. The delay in the registration of the establishment of a Limited Liability Company may be due to the delay in the process of making the Company's NPWP by its own Limited Company, or for other reasons which result in the date of registration cannot be registered with $\mathrm{SABH}$ and the previously purchased voucher has expired. Regarding the use of the affirmation deed, because of the previous deed of establishment had become an official and included in the notary protocol, the existence cannot be withdrawn. To avoid delays in registration, the notary should conduct socialization to clients who will carry out the process of establishing a Limited Liability Company.

Keywords: Limited Liability Company; Legal Entity Administration System; Delay
\end{abstract}

\section{Introduction}

A limited liability company, hereinafter referred to as a company, is a legal entity which is a capital alliance. It is established based on an agreement. It runs its business activities with authorized capital which is entirely divided into shares and fulfilling the requirements set forth in the laws and implementing regulations. This definition is based on the provisions of Article 1 number (1) of Law Number 40 year 2007 concerning Limited Liability Companies (UUPT). As a legal entity, the company was established and created through a legal process. Moreover, according to M. Yahya Harahap, the company is an artificial legal person that distinguishes it from a human being as a legal person who is established through a natural process and attached to his rights from birth to death. ${ }^{3}$

The Company as a legal entity was created and established through procedures as specified in the Company Law. The company is legally valid with the rights and obligations attached to it after obtaining approval from the Minister of Law and Human

\footnotetext{
${ }^{1}$ Master of Notary's Student Sultan Agung Islamic University (UNISSULA) Semarang email budianimeta@gmail.com

${ }^{2}$ Lecturer of Faculty of Law UNISSULA

3 M. Yahya Harahap 2011 Hukum Perseroan Terbatas Cetakan Ketiga Sinar Grafika Jakarta page 53
} 
Rights. As an artificial legal entity, the company is not fictitious but actually exists in the community by conducting business activities as stipulated in the purposes and objectives of the company in the Articles of Association.

The Company is a legal entity that has been approved by the Minister which was established based on the agreement of the founders of the company in an agreement. The Articles of Association constitute the realization of the agreement in the sense that a company's Articles of Association basically contain agreements between the parties involved in the company, in this case the Company's organs. The Company's organs consist of a General Meeting of Shareholders (hereinafter referred to as the GMS), Directors and Board of Commissioners ${ }^{4}$. Each organ has their respective rights and obligations regulated in the Articles of Association of the Company, so that if a company wants to change its Articles of Association, it requires approval and or notification to the Minister. Amendments to the Articles of Association must obtain approval from the General Meeting of Shareholders (GMS). The results of the GMS regarding the amendment to the Articles of Association mandated by the UUPT (Limited Liability Law) must be published and stated in the Notarial Deed in Indonesian. ${ }^{5}$

To establish a Limited Liability, it deemed needs an official deed (deed made by a notary) in which other names of limited liability companies, capital, business fields, company addresses, and others are included. This deed must be approved by the Minister of Law and Human Rights of the Republic of Indonesia (formerly the Minister of Justice). To get permission from the minister of justice, it must meet the following conditions:

- Limited companies do not conflict with public order and decency

- The deed of establishment fulfills the requirements stipulated in the Law

- At least $25 \%$ of the issued and paid up capital from authorized capital. (in accordance with Law No. 1 of 1995 \& Law No. 40 of 2007, both regarding limited liability companies).

The role of a Notary in making a deed relating to a Limited Liability Company as stipulated in article 7 paragraph (1) of the Republic of Indonesia Law Number 20 year 2007 concerning Limited Liability Companies which states: "The Company is established by 2 (two) or more persons with a notary deed made in Indonesian. "6

Made by/before a notary in connection with a Limited Liability Company are: Deed of Establishment of Limited Liability Company, Deed of amendment of Limited Liability Company, Deed of Transfer of Shares, Deed of PKR (Statement of Meeting Resolutions) on GMS (General Meeting of Shareholders) of Limited Liability Company, Deed of Minutes of GMS of PT (Limited Liability).

In connection with the deeds made above which contain matters as regulated in the Limited Liability Company Law, an application is requested to obtain a ministerial decree concerning the legalization of a legal entity electronically. The procedures stipulated in the Limited Liability Company Law that the founders jointly or by authorizing the notary to submit the application by filling out the electronic form. An electronic application must be completed with a description of the supporting documents in the form. If the information regarding the supporting documents is in accordance with the provisions of the legislation, a statement will not be issued against

\footnotetext{
${ }^{4}$ Pasal 1 ayat (2) UUPT.

${ }^{5}$ Article 19 paragraph (1) Juncto Article 21 paragraph (4) of the Company Law.

${ }^{6}$ Mulyoto 2016 Kriminalisasi Notaris dalamPembuatan Akta Perseroan Terbatas (PT) Cakrawala

Media Yogyakarta page 12
} 
the minister. Based on Article 10 paragraph (1) of Law Number 40 of 2007 concerning Limited Liability Companies, an application to obtain a Ministerial Decree must be submitted to the Minister no later than 60 (sixty) days from the date of the establishment deed, complete with information on supporting documents.

Applicants who want to establish a Limited Company must at least have to prepare 3 company names (using 3 syllables) because there is a possibility that the name they want is already used by someone else. In filing the name of the company the applicant must pay attention to the Government Regulation of the Republic of Indonesia Number 43 year 2011 concerning the procedure for submission and the use of the name of the Limited Liability Company, with due observance to articles 5 and 11 which essentially are: ${ }^{7}$

- The company must use the company name in Indonesian if all of its shares are owned by Indonesian citizens or Indonesian legal entities, the use of foreign languages may only be for PT. PMA or if there is one shareholder of a foreign national.

- The name has never been used legally by another PT or not the same as basically the name of another company (to avoid any third party claim);

- Not the same or not similar to state institutions, government agencies, or international institutions, except obtaining permission from the relevant institution;

- The name must be in accordance with the purpose and objectives and business activities (in the event that the purpose and objectives and business activities will be used as part of the company name), or vice versa the name may not be specific with the purpose and objectives and business activities if the purpose and objectives and activities of the company are general.

Names that contravene PP No. 43 year 2011 are the responsibility of the applicant, and the Ministry of Law and Human Rights of the Republic of Indonesia has the right to cancel orders for names that are not in accordance with the PP. 8

After the name of the Limited Liability Company is approved by the Minister, then the Founders submit an application to the Minister to obtain a Ministerial Decree concerning the ratification of the Limited Liability Company as a Legal Entity. The application is submitted electronically through the information technology system of the legal entity administration system (Sisminbakum), by filling in the form specified. The form format contains at least:

- Name and domicile of the Company.

- Term of establishment of the Company.

- The purpose and objectives and business activities of the Company.

- Amount of authorized capital, issued capital, and paid up capital.

- Complete address of the Company.

The application must be submitted to the Minister within no later than 60 days from the date the Deed of Establishment (Articles of Association) is signed and completed with information on supporting documents. If the application is not submitted within the period, the Company's Deed of Establishment will be canceled since the expiration of the period. With the passage of time, the Company that has not obtained legal status is disbanded legally and the settlement is carried out by the Founders themselves. If the content format and supporting documents in the application are in accordance with the time period and do not conflict with the laws and regulations, the Minister directly states that he has no objection to the application submitted. The

\footnotetext{
${ }^{7}$ Advendi S. Hukum Dalam Ekonomi. Jakarta: Grasindo. 2008 page.21

8 http://rulindo.blogspot.com/2016/02/aturan-pesan-nama-pt-perseroan-terbatas.html
} 
statement was delivered electronically. Conversely, if it is not in accordance with the provisions of the legislation, then the Minister immediately notifies the rejection and the reason for that to the Petitioner, also the submission is done electronically.

Based on the above problems, the writer examined with the title "Responsibility of Notary to the Delay in Registration of Establishment of Limited Liability Company in Legal Entity Administration System (SABH) Ministry of Law and Human Rights in accordance with Law Number 40 year 2007 concerning Limited Liability Companies."

A limited liability company, hereinafter referred to as a company, is a legal entity which is a capital alliance, established based on an agreement, conducting business activities with authorized capital which is entirely divided into shares and fulfilling the requirements set forth in the laws and implementing regulations. This definition is based on the provisions of Article 1 number (1) of Law Number 40 of 2007 concerning Limited Liability Companies (UUPT). As a legal entity, the company was established and created through a legal process. According to M. Yahya Harahap the company is an artificial legal person that distinguishes it from a human being as a legal person who is established through a natural process and attached to his rights from birth to death. ${ }^{9}$ The Company as a legal entity was created and established through procedures as specified in the Company Law. The company is legally valid with the rights and obligations attached to it after obtaining approval from the Minister of Law and Human Rights which the writer then calls the Minister for further. As an artificial legal entity, the company is not fictitious but actually exists in the community by conducting business activities as stipulated in the purposes and objectives of the company in the Articles of Association.

\section{Research Methods}

The method used in this research was an empirical juridical method, namely the juridical method used to analyze Law Number 40 year 2007 concerning Limited Liability Companies. The empirical method was used to analyze the responsibility of a Notary Public to the delay registration of the establishment of a Limited Liability Company in the Ministry of Legal Entity Administration System, the Ministry of Law and Human Rights in accordance with the provisions of Law Number 40 year 2007 concerning Limited Liability Companies. It means, the object of the problem or the one being examined was the issues that were regulated normatively in the legislation.

Research specification used in this research was descriptive analysis. Descriptive analysis research is research that aims to provide as insightful images as possible about humans, other conditions and symptoms ${ }^{10}$, or research to collect data, compile, and clarify, analyze, and interpret. ${ }^{11}$

Research material sources were generally distinguished on materials obtained directly from the community and from library materials. As for what was obtained from library materials is called secondary material. This research was better focused on library research and other materials that can support in relation to the discussion of the problem.

\footnotetext{
9 M. Yahya Harahap 2011 Hukum Perseroan Terbatas Cetakan Ketiga Sinar Grafika Jakarta page 53

${ }^{10}$ Sutrisno Hadi 1984 Metode Research Jilid I Yayasan Penerbitan Fakultas Psikologi UGM Yogyakarta page 19

${ }^{11}$ Soenarjo 1985 Metode Riset I Universitas Negeri Sebelas Maret Surakarta page 8
} 


\section{RESEARCH RESULTS AND DISCUSSION}

Initiate a discussion about notary accountability for the delay in registering the establishment of a Limited Liability Company in the Legal Entity Administration System (SABH) in accordance with Law Number 40 year 2007 concerning Limited Liability Companies, the researcher determine the discussion aims to minimize delays in the registration of limited liability companies at SABH so that they become orderly and maximize the service of Notaries to clients. To overcome the delay in the registration of the establishment of the Limited Liability Company, it is done by using an affirmation deed of the previous deed of establishment which has expired. In this case is for more than 60 days. Since the registration of the establishment of a limited liability company in SABH has been done online, so that it has been integrated and cannot be tolerated regarding the late registration of the establishment of the Limited Liability Company. ${ }^{12}$ Article 21 paragraph (1) of the Limited Liability Law states that the Limited Liability Establishment Deed which has been approved by the Minister subsequently must be registered in the Company Register in accordance with the provisions stipulated in Law No.3 year 1982 concerning Obligatory Company Registration (WDP).

The things that must be registered are: ${ }^{13}$

- Deed of establishment in accordance with the ratification of the Minister of Justice.

- Deed of amendment to the Articles of Association along with the approval letter of the Minister of Justice.

- Deed of amendment to the Articles of Association and Report to the Minister of Justice.

Registration of the Deed of Establishment and the amendments to the above amendments must be made no later than 60 (sixty) days after approval or approval has been given or after receipt of the report.

The limited liability (PT) that has been registered must be announced in the Supplement to the State Gazette of the Republic of Indonesia (Article 22 of the PT Law). The announcement is made within 60 (sixty) days after registration. During registration and the announcement has not been made, the members of the Board of Directors are jointly responsible for all legal actions committed by the company (Article 23 of the Law on PT). Legal Sanction of Limited Liability Company Violation or negligence in carrying out the obligation to register and announce the establishment of PT is threatened with criminal or civil sanctions. Company directors who do not carry out the obligation to register the company in the Company Register and announce in the Supplement to the Republic of Indonesia State Gazette are subject to sanctions of imprisonment or fines.

In connection with the application of the affirmation deed, the Limited Liability Company can still be registered because the previous Deed of Establishment has become an official and entered the notary protocol so that it cannot be withdrawn. The affirmation certificate states that prior to the signing of the deed of establishment of the Limited Liability Company concerned. Previous deeds cannot be registered because the date has exceeded 60 (sixty) days.

It is different from affirmation certificate, the name of message vouchers must be processed again, because the voided voucher cannot be re-registered. ${ }^{14}$

\footnotetext{
${ }^{12}$ Sudarsono 2007 Kamus Hukum Cet. V Rineka Cipta Jakarta page. 39

${ }^{13}$ Asyhadie Zaeni. 2012 Hukum Bisnis Jakarta: PT Raja Grafindo Persada page.44

${ }^{14}$ Interview with Ms. Setyowati at the Ministry of Law and Human Rights Central Java Regional

Office dated June 282018
} 


\section{Closing}

\subsection{Conclusion}

Based on the results of the research that has been discussed, the following conclusions can be drawn: Notary Accountability for delays in registration of Limited Liability Companies in the Legal Entity Administration System (SABH) Ministry of Law and Human Rights In accordance with Law Number 40 year 2007 concerning Limited Liability Companies are as follows:

- Make an affirmation deed to confirm the previous deed of establishment whose date has expired. Make a new deed so that the date can be registered in SABH.

- Order a voucher to order the name of the company again, because the expired voucher cannot be used.

Registration Period of Establishment of Limited Liability Company is 60 (sixty) days. Sixty days in this case is sixty calendar days, not sixty working days. Because it is already integrated in the Legal Entity Administration System, registration is done online.

\subsection{Suggestion}

It is better for Notaries to provide clear information to clients to minimize the delays in registering limited liability companies. Because the orderly registration shortens the working time so it doesn't repeat twice and is more efficient.

In addition to the client should also follow the existing procedures to avoid problems that should not occur.

\section{References}

[1] M. Yahya Harahap, 2011, Hukum Perseroan Terbatas, Cetakan Ketiga, Sinar Grafika, Jakarta

[2] Mulyoto, 2016, Kriminalisasi Notaris dalamPembuatan Akta Perseroan Terbatas (PT), Cakrawala Media, Yogyakarta

[3] Sutrisno Hadi, 1984, Metode Research Jilid I, Yayasan Penerbitan Fakultas Psikologi UGM, Yogyakarta

[4] Soenarjo, 1985, Metode Riset I, Universitas Negeri Sebelas Maret, Surakarta,

[5] Sudarsono, 2007, Kamus Hukum, Cet. V, Rineka Cipta, Jakarta

[6] Advendi S. 2008 Hukum Dalam Ekonomi. Jakarta: Grasindo.

[7] Asyhadie, Zaeni. 2012,"Hukum Bisnis",Jakarta: PT Raja Grafindo Persada,

[8] Wawancara dengan Ibu Setyowati di Kementrian Hukum dan Hak Asasi Manusia Kantor Wilayah Jawa Tengah, tanggal 28 Juni 2018

[9] UU Nomor 40 Tahun 2007 tentang Perseroan Terbatas

[10] http://rulindo.blogspot.com/2016/02/aturan-pesan-nama-pt-perseroanterbatas.html 